\title{
Teaching Anthropology

\section{Teaching Socio-Cultural Anthropology In Albania: Bringing Together Professional Training And Active Citizenship}

\author{
Esmeralda Agolli \\ Department of Archaeology and Culture Heritage, University of Tirana
}

\begin{abstract}
With the collaboration of: Olsjan Alikaj, Era Frakulli, Luena Golemi, Ilirjana Idrizaj, Arnold Kapinova, Klevis Qeleshi, Elisa Shkurtaj, Andia Shtëmbari
\end{abstract}

Alumni students of the Department of Archaeology and Culture Heritage, University of Tirana

\begin{abstract}
Anthropology in Albania has been addressed mainly during the last two decades or so. Previously, the most common research agendas focused on the explorations of folklore and ethnography and indeed the venue that carried out research was the Institute of Folk Culture. As a consequence, teaching has been narrowly treated through the perspective of the folkloric and ethnographic studies, mostly the exotic and narrative terms. Currently, various tenets of anthropology are taught in the departments of Humanities and Social Sciences such as in History, Archaeology and Culture Heritage, and Sociology. In this paper, I discuss the benefits of anthropology as a core subject in the curricula of the Bachelor program of Archaeology and Culture Heritage. Three main aspects are considered: first, the extent to which social and cultural anthropology contributes to the understanding of the dynamics of human behaviour in a timeless perspective. Due to the state of preservation, and the nature of the archaeological data, scientific analysis and investigations are often extremely limited. The theoretical and methodological tenets, as well as particular case studies treated from cultural anthropology play an indispensable role in this endeavour. Second, I deal with the impact of social anthropology in the student background and how its concepts and methodological tools can contribute to a better understanding of a society in action and transition. To what extent can we employ anthropology to help understand and analyse how tradition and modernity combine? Third, by drawing a survey completed by a selected group of students, I discuss how studying anthropology facilitated the student involvement in the professional context as well as strengthened their critical thinking skills and fostered active citizenship.
\end{abstract}

Keywords: Albania; Teaching; Anthropology; Tradition; Patriarchalism; Modernity

\section{Introduction}

In Albania, anthropology is generally considered an elitist discipline, with an exclusive focus on research and a peripheral subject in the university teaching curricula. At best this is illustrated by the very fact that to this day, an independent anthropology department is not yet a reality at any university in the country. The discipline continues to develop within the structure of research centres or institutes. The primary focus on research is mainly associated with activities that include fieldwork, seminars, conferences, or publications. The so-called doctoral school is the only qualification program, which, however, does not overcome the research-oriented fashion of the centre.

Interesting dynamics can be observed with the character of anthropological research as well. During the last two decades some efforts, especially on the theoretical framework of the discipline, have built a vivid debate (Bardhoshi 2010, 2015, Hysa 2010, Stephanie Schëander-Sievers 2012). However, a comprehensive evaluation of the potential of anthropological teaching in the university curriculum still remains peripheral. A fundamental issue to be addressed then, is to what extent can anthropology in Albania break from the research bubble and expand its focus on to teaching and the preparation of professionals for a career in anthropology.

Traditionally, the Institute of Anthropology is provided for by expertise from different disciplines, such as history, arts, law, music and so on. Archaeology developed in a similar fashion. Both fields followed similar theoretical trajectories, but rather sharply divided on their respective operating grounds and lacking exploration 
of mutual research endeavours. In Albania, especially within the university curricula, archaeology and ethnology traditionally met in history departments. However, even in these circumstances, each discipline would mostly care about accomplishing its own narrow focus. In archaeology, the curricula followed the historical perspective, studying only those human contexts which lack written records, mostly prehistory and Greco-Roman civilizations. On the other hand, ethnology limited its focus to Albanian issues associated with narratives on ethnography and folklore. The establishment of the Department of Archaeology and Culture Heritage at the University of Tirana in 2013 brought a new reality to the field of humanities. The teaching curricula of this department, aimed to remedy flaws inherited from the traditional division of disciplines. The department has a vocation on theory, interdisciplinary research, data analysis as well as reflections and education on actual matters in civil, cultural and political issues. An experience of five years in this department, with a particular involvement in the courses of anthropology, has inspired the issues in the discussion that follows.

\section{Cultural Anthropology and Archaeology}

Since the foundation of the four-field discipline from Franz Boas (1904:468-482), anthropology and archaeology, especially in the USA, have had an inseparable connection. Recently, Bernard Wood, discussing the status quo of the four-field discipline, argues that new dynamics in the field, including hypothesis-driven research, the growing expertise, and the increase of cooperation within research projects have called into question the cohesion of the so-called 'sacred bundle' (a term coined by Stocking 1988) that Franz Boas implemented a century ago (2013:152155). Despite this discussion, in the endeavour of the archaeologist to understand human behaviour through the archaeological data, the implication of the anthropological tenets have not been compromised, but have rather grown stronger. Ethnoarchaeology - an emerging field in Archaeology - covers rather comprehensively the dynamics of this intertwinement. To turn to the Albanian context, 'Cultural Anthropology' is an A-level course, designed for students of Archaeology and Culture Heritage and, as I discuss below, has three main pedagogic benefits:

\section{How to Shape our Thoughts Through Theory}

It is crucial for students to be enabled to frame comparisons between the traditional approaches of historical archaeology versus the ramifications of the anthropological tenets. A discussion of the theoretical agendas that led to the epistemology of anthropological thought is followed by a discourse of the methodological protocols applied in the data collection and assessment. Archaeological theory in itself has had an intimate connection with anthropological theory since its inception. In particular, issues that have influenced the Albanian research agenda and more broadly the Balkan region include nationalism and ethnocentrism. Even in normal discussions with students, an ethnocentric tendency to perceive particular cultural traditions of the everyday life as exclusive creations of their own cultural and national background can commonly be noted. This kind of 'pride' is expressed even through cultural traits like folk music, traditional dresses, or food, easily find counterparts in every country of the region. Even attractive features of the landscape where human intervention has had no effect at all, are at times thought of with pure and romantic pathos. Adela Peeva, in her documentary 'Whose is this song', portrays this tendency of exclusivity in the Balkan countries (Peeva 2009). By bringing this case into discussion, students have the opportunity to evaluate how ethnocentrism shapes our perceptions on viewing others and also understand how nationalist agendas mingled with politics have cultivated divisive strategy in the region. A simple song could alter these ill-defined perceptions and effectively exemplify a new avenue that allows students to see how, through communication and networks, communities around the region have lived and exchanged over time.

\section{The Active and Passive Context of Human Behaviour}

Ethnoarchaeology deals quite extensively with the benefits and the methodological emphasis of the active and passive conjunction. The goal of cultural anthropology in the second year of the undergraduate studies is crucial for acknowledging how some fundamental mechanisms that operate in non-modern societies could meet their counterparts in the archaeological record. We discuss to what extent a non-modern society can be approached in a holistic framework. How can we deal with the socio-cultural context of the past in a diachronic and synchronic perspective, and what kind of questions can or should we ask? Attention is given to the nature of interactions of human behaviour and the content of the course includes topics like communication, language, culture, economy, social divisions, politics, marriage, gender, kinship and religion. In most cases, the archaeological data is fragmentary and poorly preserved and, in the attempt to understand a perished context of human behaviour, the content of non-modern societies may serve to highlight, for example, socio-politic 
organization, technology, settlement pattern, exploitation of environment, strategies of defence and attack, gender, kinship, death and religion.

\section{Students Mingling Between Tradition and Modern Values}

How do traditional culture, kinship and patriarchal relations influence Albanian society and what kind of tensions have their encounter with modern context met? Albania is still a country where traditional customs and rituals play a crucial role in society. Every academic year in the department there are students from every corner of the country, both urban and rural. Teaching cultural anthropology has resulted in a dual process. For students coming from a traditional background, any mention of traits, actions and customs that are cultivated into them inspire expressions of pride. This attitude at times leaves little space for rational reasoning and critical thinking. Some crucial issues that Albanian society still suffer from today are rooted in the unwritten laws and order of this traditional environment. For example, interpersonal relations, including inheritance rights of girls at the parents' house or gender issues within the patriarchal family are some of the most discussed matters. Generally, students give crucial importance to equal rights and shared responsibilities within the family. However, there are cases in which traditional customs are not called into question, but rather perceived as a more effective way of organisation. Especially with rights of inheritance in rural areas, where there is a tendency to avoid state law and apply traditional patrilineal rules. It is assumed that sons have exclusive rights to inheritance and daughters are 'compensated' through their future husband's estate and capital. Discussions on this topic have brought some interesting dynamics. The majority of students express openly and strongly in favour of equal gender rights. There is however, a handful of students that show no confidence in state

laws and rely more confidently on the patriarchal ways of life. Corruption and the elongated transition in Albania have made embracing modern values and rule of law quite challenging. As a consequence, relying on family ties is still perceived as an effective way of living. It is not a difficult task to make students aware that patriarchal ways of life are in a constant clash with the values of a modern society. However, in 'real' life and outside the auditoriums, they meet with an environment that does not foster such modern values.

\section{Socio-Cultural Anthropology}

'Socio-Cultural Anthropology' is a core course taught in the third year at the undergraduate level. In contrast to Cultural Anthropology, the goal is to acquaint students with a global perspective and understanding of the variations of human behaviour. The core reading is the textbook of Thomas Hylland Eriksen (2001) and some other readings with a closer focus on Albanian society, including the journal 'Përpjekja' (https://www.revistaperpjekja.org/). The course deals with a wide array of topics including the social person, community, politics, technology, production and ethnicity. The sessions of the first part emphasize the history of anthropological thought, followed then by a discussion of salient theoretical approaches. In terms content, this is an advanced version of the theoretical focus treated earlier in the course on cultural anthropology. Beyond theory however, the course conveys two additional goals in a local and global perspective through special topics:

1) It aims to challenge a regionalist focus that Albania conveys as culture and society, and attempts to expand focus to universal phenomena and examples or case studies that are relevant to Albania. For instance, students commonly take for granted that documents like the Universal Declaration of Human Rights and their implementation, is an enterprise beyond the practical concerns of the individual. Not to mention here that a good portion of students are not aware of such a document. A similar reaction can be noticed with perceptions of the 'other'. Due to a long-lasting influence of the patriarchal order, communism, as well as the homogeneous ethnic background of Albanian society in general, a sense of prejudice, or at best, astonishment, can often be noted when norms and behaviours are notably different from the native cultural background. These perceptions enclose the circle of 'accepted' behaviours and norms only to those customs with which someone is locally cultivated. Attempts to break through this tendency are not always a successful enterprise. However, by taking this impediment into account, the course widens the focus to various socio-cultural contexts around the world, including modern and non-modern societies.

2) It raises awareness for sensitive issues faced by society today, such as corruption, migration, racism or sexual orientation. It is here that the active citizenship and social values gain particular importance. It would be impossible to discuss corruption in the Republic of Congo without discussing the situation in the country. Discussions in this matter include a wide range of cases that students themselves have experienced in their everyday life. It is discouraging that such issues concern especially their career trajectory. Racism is another focal issue. Prejudices and racist reactions, mainly towards minorities in the country, are very evident. In particular the 
Roma and Egyptian communities are still perceived as segregated groups. Examples of their culture (Roma and Egyptian communities) and ways of living are discussed in order to smooth boundaries and see these groups as an integral part of society (UNDP Albania 2015). Migration became another crucial topic of discussion. It is impossible to encounter an Albanian family that has not experienced migration - at least through a family member - to western Europe or the United States. Moreover, especially due to interior problems like corruption, unemployment and poor access to health services, the younger generation tends to leave the country. A recent study from the Institute for Democracy and Mediation shows that one in two Albanians feel enthusiastic about leaving the country (IDM Trust in Governance 2019). Quantitatively this is more significant within the younger generation. Migration and its impact on the society is extensively discussed and students are aware of a wide range of phenomena that are the result of global movement especially socio-economic impact, and communication. However, society has developed a largely migratory culture while immigration is not yet perceived as a potential scenario. Sexual orientation is addressed in various lectures, especially when human rights come to the fore of the discussion. There are major problems with regard to their acceptance in Albania. The discussion brings into attention studies conducted with the LGBTQ community in Albania which show that students of a different sexual orientation (LGBTQ) do feel highly stigmatized both in society and with their family and prefer not to come out (Qendra Streha, 2018).

\section{What Did the Students Say?}

I now turn to student feedback for both courses. The students selected here are those that have completed their Bachelor program. Nine students chose to discuss three main topics using a standard questionnaire. The first questions asked if both courses, cultural and socio-cultural anthropology, were beneficial in their professional growth. Every student answered positively for both courses. The second category had six questions asking about any experienced benefits and any reflections on the courses in strengthening their professional skills. Below is the list of questions:

\begin{tabular}{|l|l|}
\hline 1. & Have you been able to apply any concept in your work or research in the past? \\
\hline 2. & Where did you include this background in your work? \\
\hline 3. & What was the major difficulty? \\
\hline 4. & Did they improve your skills in critical thinking? \\
\hline 5. & What are three main problems that impressed you at most? \\
\hline 6. & What would you miss if these courses would not be part of the curricula? \\
\hline
\end{tabular}

For questions 1 and 4, every student offered positive feedback. For question 2, they provided a much wider variety of replies, mentioning research for their thesis, critical thinking, empirical data and the understanding of cultural variations as the main aspects in which they considered the background of the courses as useful. The most common difficulties (question 3) concerned the learning of new terminology and critical thinking skills. In regards to question 5, issues like cultural interaction, nationalism, racism, gender, politics and power, sociopolitical organization, were the topics that made the greatest impression on the students. Students mostly emphasized that if the courses had not been taught, they would have not learned about the various dimensions of human behaviour, and would not have gained further awareness of how to see different perspectives on the development of a society.

The third category included questions that dealt with their activity as social agents in society. Four questions were asked here:

\begin{tabular}{|l|l|}
\hline 7. & $\begin{array}{l}\text { Did the course focus on current socio-cultural problems: } \\
\text { racism, social divergence, regional divergences, nationalism, ethnocentrism, gender, patriarchalism, property issues, } \\
\text { sexual orientation, migration, globalization? }\end{array}$ \\
\hline 8. & Did discussions in classroom impact your previous perceptions? \\
\hline 9. & Did you expand your knowledge? \\
\hline 10. & Do you have any suggestion for future improvements in both courses? \\
\hline
\end{tabular}

Generally, the students expressed their awareness for each of the topics addressed in question 7. In question 8, some of them point to ethnocentrism, nationalism and sexual orientation as topics that had the greatest impact 
on previously held perceptions. They largely agree that they had expanded their knowledge (question 9), and a few recommend that future classes focus more on practice, local issues, social divergences and sexual orientation.

The student assessments indicate the crucial importance of both courses in the curricula. However, the difficulties with the two main aspects of terminology and critical thinking reflect gaps that students inherit from earlier phases of education. Curricula in intermediary and high school remain oriented towards scholastic and pedantic methodology mostly based on erudite knowledge. While discussing this issue with Professor Roland Gjini, who has many years of experience and a background in pedagogy and teaching at the University of Elbasan, he mentioned that the school curricula in Albania still do not perceive knowledge, expertise and education in an integrative framework. As a consequence, students see courses exclusively as a venue where they learn scholastically a particular set of concepts without worrying much about how to integrate or apply them elsewhere. The questions that have somewhat remedied this situation are those that evoke the importance of empirical data, nationalism, racism, and ethnocentrism. All these matters served to them a dual purpose; as key concepts to operate in a professional domain as well as seen as focal topics that have deeply shaped perceptions and attitudes towards the variability of human behaviour.

\section{Conclusions}

I started to teach these two courses with a strong emphasis on the professional training, focusing especially on the ramifications of cultural anthropology in the study of the past and putting an emphasis on concepts and themes that have not been thoroughly considered in archaeology. Indeed, in this realm, anthropological theory and any consideration of the ethnographic context of non-modern societies have contributed extensively to how the past is to be perceived through archaeological data. The 'sacred' bundle in a mutual connection of archaeology-cultural anthropology has proven to be quite sacred! However, the impact of anthropology on civil values goes beyond its simple professional implications for archaeology. For a society in transition, and with strong patriarchal influence, teaching concepts of social and cultural anthropology that evoke critical and independent thinking have beneficial results and challenge regionalist attitudes towards various phenomena mainly related to the ways individuals perceive 'others'. The students have stressed that for matters like nationalism and ethnocentrism, the courses greatly improved their reasoning. One main issue of society largely reflected in the classroom, is the struggle to completely disconnect from patriarchal ways of living. Even more problematic is the fact that such does not come from conservative tendencies within the family, but rather from an inability of politics and society to offer a real potential for fairness and order outside the constrains of family shelter. However, it must be stressed that anthropology in Albania needs to propel itself out of the research 'bubble' with a proper perspective on education and teaching. Anthropology has a lot to offer for many of the social problems in the country, problems that are either inherited from the attitudes of traditional society or the ways modernity is embraced and perceived.

\section{Disclosure statement}

No potential conflict of interest was reported by the authors.

\section{References}

Bardhoshi, N. (2010), 'Për një antropologii të modernitetit Shqiptar', Kultura Popullore, 1-2:127-150.

Bardhoshi, N. (2015), 'Mbi Etnografinë për fisin dhe farefisninë nga Rrok Zojzi', Kultura Popullore, 1-2:45-72

Boas, B. (1904), 'The History of Anthropology', Science, 20:512, 513-524.

Eriksen, H. Th. (2001), Small Places, Large Issues: An Introduction to Social and Cultural Anthropology, London: Pluto Press.

Hysa, A. (2010), 'Ethnography in Communist Albania: Nationalist Discourse and Relations with History', Historicni Seminar 8, 103-125.

Institute for Democracy and Mediation/Trust in Governance 2019: https://idmalbania.org/public-opinion-polltrust-in-governance-2019/ 
Teaching Anthropology 2021, Vol. 10, No. 2, pp. 7-12.

Peeva, A. (2003). 'Whose Is This Song?', TV Documentary. USA.

Qendra Streha 2018:Pengesat E Hasura Nga Komuniteti Lgbti Në Marrjen E Shërbimeve Ligjore Dhe Aksesit Në Drejtësi. Save the Children. https://albania.savethechildren.net/sites/albania.savethechildren.net/files/library/Studimi\%20$\%$ 20Streha.pdf

Revista Përpjekja: https://www.revistaperpjekja.org/

Schëander-Sievers S. (2012), 'Virgjëreshat" dhe "Elefantët në dyqanin e qelqurinave": Rreth sfidave ndërkombëtare të etnologjisë shqiptare', In: O. Schmitt and E. A. Frantz (eds.) Gjendja dhe Prespektivat e Studimit të Historisë së Shqiptarëve, Perpjekja 219-254.

Stocking, G. W. (1988). 'Guardians of the sacred bundle: The American Anthropological Association, and the Representation of Holistic Anthropology'. In Learned societies and the evolution of the disciplines. ACLS Occasional Paper no. 5. S. B. Cohen, D. Bromwich, and G. W. Stocking, eds. Pp. 17-25. New York: American Council of Learned Societies.

UNDP Albania (May 15, 2015) Roma and Egyptians in Albania: a socio- demographic and economic profile. https://www.al.undp.org/content/albania/en/home/library/poverty/ roma-and-egyptians-in-albania--asocio--demographic-and-economi.html

Wood, B. (2013). 'Four-field Anthropology: A Perfect Union or a Failed State?', Symposium: The changing shape of bigher education since the 1960s, 50:152-155. 